\title{
PHYLOGENETIC STUDY OF THE GENERA MICHAUXIA L'HÉRIT., ASYNEUMA GRISEB. ET SCHENK AND LEGOUSIA DURAND (CAMPANULACEAE) IN THE KURDISTAN REGION- IRAQ
}

\author{
SHILAN, A. H. ${ }^{*}$ - JAWHER, F. S. \\ Department of Biology, College of Education, Salahaddin University-Erbil, Iraq \\ *Corresponding author \\ e-mail: shilan.husain@su.edu.krd; phone: +96-4075-0456-8479 \\ (Received $2^{\text {nd }}$ Mar 2020; accepted $25^{\text {th }}$ May 2020)
}

\begin{abstract}
Campanulaceae are a highly diverse clade of angiosperms. Chloroplast markers have greatly improved our understanding of this clade, but many relationships remain unclear primarily due to low levels of molecular evolution and recent and rapid divergence. Furthermore, focusing solely on maternally inherited markers such as those from the chloroplast genome may obscure processes such as hybridization. We explore the phylogenetic utility of two low-copy nuclear loci from the pentatricopeptide repeat gene family (PPR). Rapidly evolving nuclear loci may provide increased phylogenetic resolution in clades containing recently diverged or closely related taxa. We present results based on chloroplast and low-copy nuclear loci, and discuss the utility of such markers to resolve evolutionary relationships and infer hybridization events within Campanuloideae clade. The phylogeny of the genera Michauxia, Asyneuma and Legousia in Kurdistan Region was investigated by using eight in-group species and one out-group related genus Campanula conferta, based on the matK-KIM intergenic region of chloroplast DNA and internal transcribed spacer of nuclear ribosomal DNA. Individual and combined analysis of mat $K$-KIM and ITS2 sequence data indicated monophyly of the Asyneuma and Legousia genera, the results for bayesian and maximum parsimony displayed three clades of Michauxia, Asyneuma, and Legousia with high supports (bs $=76 \%$, pp $=0.100$ ).
\end{abstract}

Keywords: Bellflower family, matK-KIM, ITS2, evolutionary relationships, phylogeny

\section{Introduction}

The genera Michauxia, Asyneuma, and Legousia, belong to the family Campanulaceae (Bellflower family), which is the second-largest family in the Asterales and third most abundant family in the campanulate, Jussieu formally described it in 1789 (Hansen, 2016). Campanulaceae family belonged to the Orders: Campanulate, Subclass: Asteridae and Class: Magnoliopsida (Cronquist, 1981; Watson and Dallwitz, 1992).

The family includes 84 genera and 2330 species, which are widespread in the world except for the major desert regions (Byng, 2014), while in the Kurdistan region of Iraq, the family includes 4 genera and 26 species distributed in different districts (Ghazanfar and Edmondson, 2013). The family (Campanulaceae s. str.) classification systems have historically followed the arrangements of Boissier (1875) and Schönland (1889), along with the refinements of Charadze (1949, 1970, 1976), Fedorov (1957), which can eventually be traced back to the arrangement of De Candolle (1839) who divided the family into two subtribes, the Campanuleae and the Wahlenbergeae, based on the mode of capsule dehiscence although Schönland split the family into three subtribes, Platycodon A. DC., Musschia Dum. and Microcodon A. DC segregated. The Platycodinae subtribe is based on the calyx lobe position concerning the locules of the ovary. Such natural classifications were necessarily based on the morphology of the calyx (e.g., the presence or absence of appendages between the lobes) or of the mode of capsule 
dehiscence (e.g., whether it is apical and valvate or lateral and porate). Many authors (e.g., Hutchinson, 1969; Carolin, 1977; Cronquist, 1988; Takhtajan, 2009) considered Cyananthus A. DC. to be the most primitive genus within the family based on its superior ovary (Eddie et al., 2003).

Phylogenetic reconstruction is now an essential tool for biologists to understand the processes that govern the evolution of organisms. Restoration of divergence times and past biogeographical ranges has grown in importance. It is reflected in the multitude of new methods developed to infer organisms' spatial and temporal evolution (Sanderson, 2002; Thorne and Kishino, 2002; Ree et al., 2005; Drummond et al., 2006). Molecular and phylogenetic methods allow researchers to obtain large, multi-gene datasets for phylogenetic studies, because of highly conserved genome organization, gene order, and gene content of the chloroplast genome across much of angiosperm diversity (Cosner et al., 1991; Haberle, 2006).

In plants, chloroplast DNA (Evans et al., 2015), nuclear ribosomal DNA (Faghir et al., 2014), and mitochondrial DNA are three molecular variations tapped for phylogenetic purposes (Yu et al., 2018). The ITS region consists of three parts: the ITS1, ITS2, and the highly conserved 5.8S rDNA exon locate between them. The Campanulaceae family undertook few molecular phylogenetic studies among it's the study of Cosner and Jansen (1993) and Cosner et al. (2004) which used structural rearrangements of chloroplast DNA (cpDNA) to establish a family phylogeny based on 18 genera, while $r b c \mathrm{~L}$ sequences for several genera were determined by Cosner et al. (1994) as part of the Campanulales interfamily relationship study.

Eddie et al. (2003) investigated the morphology of most genera of the family Campanulaceae by using cladistic and phonetic methodologies, in addition to the molecular variation of 23 to 29 taxa, he also used internal transcribed spacers (ITS2) and matK-KIM -intron sequence data from nuclear ribosomal (nrDNA) and cpDNA in another hand Eddie et al. (2003) used 93 taxa comprising 32 genera to estimate family phylogeny based on ITS sequences of nuclear ribosomal DNA also including the sequences of chloroplast genes $m a t \mathrm{~K}$ and $r b c \mathrm{~L}$, as well as chloroplast genome rearrangements and morphology data.

One of the most comprehensive studies on the Campanulaceae family was presented by Crowl et al. (2016), providing a broad phylogenetic and phylogeographic perspective that included chromosomal and morphological data. Previously, Crowl et al. (2014) had produced a first phylogenetic analysis conjointly applying several molecular markers used in previous studies within the subfamily Campanuloideae, namely the chloroplast markers atpB, matK, petD, rbcL, and trnL-F and the nuclear region ITS.

DNA barcoding is a technique in which sequences of a specific DNA region are compared for species identification. Establishing the most suitable region for plants has taken a little longer. The partial matK gene was recently adopted as the 'plant barcode' by the Consortium for the Barcoding of Life (CBOL Plant Working et al., 2009) after much deliberation. However, there are still significant challenges that need to be overcome using these DNA regions. There have been three main sets of supposedly 'universal' matK primers proposed so far: namely, 390F and 1326R, XF and 5R and 1R-KIM and 3F-KIM (Dunning and Savolainen, 2010).

The internal transcribed spacer 2 (ITS2) region of nuclear ribosomal DNA is regarded as one of the candidate DNA barcodes because it possesses several valuable characteristics, such as the availability of conserved regions for designing universal primers, the ease of its amplification, and sufficient variability to distinguish even closely 
related species. However, a general analysis of its ability to discriminate species in a comprehensive sample set is lacking (Yao et al., 2010).

The present study aims to investigate the relativeness between the genera of Michauxia, Asyneuma and Legousia based on the phylogenetic relationships and comparing with the nearest genus. For this purpose, two regions were selected, the first region is chloroplast DNA matK-1RKIM and the second is nuclear ribosomal DNA ITS2. This manuscript is a part of the author's Ph.D. dissertation.

\section{Material and Methods}

\section{Taxon Sampling}

The plant taxa used in the present study were collected from the different districts of Kurdistan region-Iraq during the period between 2017-2018 that preserved in the Herbarium of the College of Education/ Salahaddin University-Erbil and all plant samples were collected from Duhok, Zawita, Gali Ali Bag, Gali Zanta, Gara mountain, Piramagroon, Hawraman mountain and Shaqlawa (Fig. 1). Nine distinct taxa consist of eight in-group taxa and one out-group Campanula conferta were used in the analysis.

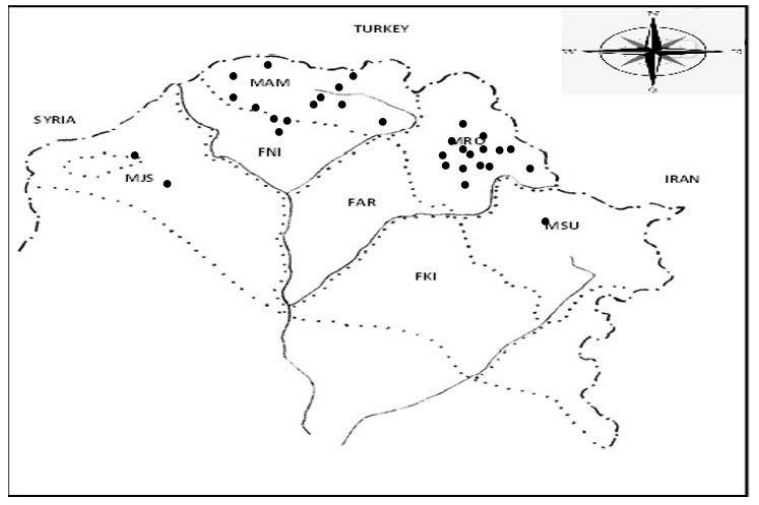

Figure 1. A map shows the distribution of the three genera species in Kurdistan Region-Iraq

\section{DNA Extraction}

According to the manufacturer's instructions, genomic DNA was extracted from collected plant specimens through the Presto ${ }^{\mathrm{TM}}$ Mini gDNA Bacteria Kit (Geneaid, Taiwan); extract was eluted with an elution buffer of $100 \mu \mathrm{L}$. Before running PCR, extracts were stored at $-20^{\circ} \mathrm{C}$. The NanoDrop 1000 spectrophotometer (ThermoFisher Scientific, USA) was used to evaluate DNA concentration and purity in which one $\mu \mathrm{L}$ of the genome DNA was used to define DNA concentration and purity.

\section{PCR and DNA Sequencing}

The two noncoding regions of nrDNA and cpDNA were amplified by using the primers $m a t K$-KIM of Dunning and Savolainen (2010), and ITS of White et al. (1990) for matK-KIM intergenic spacer and ITS region respectively (Table 1). The primers were ordered from Macrogen Company, Seoul, Korea. The total volume of amplification reactions was $25 \mu \mathrm{L}$ and the Master Mix made up of $12.5 \mu \mathrm{L}$ (the Master Mix consisting of $3 \mathrm{mM} \mathrm{MgCl} 2,0.2 \%$ Tween ${ }^{\circledR} 20,20 \mathrm{mM}$ Tris- $\mathrm{HCl} \mathrm{pH} \mathrm{8.5,}\left(\mathrm{NH}_{4}\right) 2 \mathrm{~S}_{4}, 0.2$ units $/ \mu \mathrm{l}$ 
Ampliqon Taq DNA polymerase, $0.4 \mu \mathrm{M}$ of each primer, and $0.4 \mathrm{mM}$ of each dNTP.), $3 \mu \mathrm{L}$ genomic DNA extract (density of $10 \mathrm{ng} / \mu \mathrm{l}$ ), $2 \mu \mathrm{L}$ of each primer, $5.5 \mu \mathrm{L}$ free nuclease water. The PCR-Thermal cycler for $m a t K$ gene started with 5 min for initial denaturation at $94^{\circ} \mathrm{C}$ followed by 35 cycles: denaturation at $94^{\circ} \mathrm{C}$ for $30 \mathrm{sec}$.; annealing at $54^{\circ} \mathrm{C}$ for $60 \mathrm{sec}$; extension at $72^{\circ} \mathrm{C}$ for $60 \mathrm{sec}$. And the final extension at $72^{\circ} \mathrm{C}$ for $5 \mathrm{~min}$. While the PCR program for the ITS gene started with $5 \mathrm{~min}$ for initial denaturation at $94^{\circ} \mathrm{C}$ followed by 35 cycles: denaturation at $94^{\circ} \mathrm{C}$ for $30 \mathrm{sec}$; annealing at $56^{\circ} \mathrm{C}$ for $20 \mathrm{sec}$; extension at $72^{\circ} \mathrm{C}$ for $20 \mathrm{sec}$. And the final extension at $72^{\circ} \mathrm{C}$ for $5 \mathrm{~min}$. The resultant PCR products were checked on $1.5 \%$ agarose gel run in TAE buffer. The gel was stained with Safe red dye and photographed under UV transilluminator.

Table 1. List of primers and their sequences that have used in the study

\begin{tabular}{c|c|c}
\hline Primer & Oligonucleotide Sequence & References \\
\hline ITS2-S2 & F: 5'-ATG CGA TAC TTG GTG TGA AT-3' & \multirow{2}{*}{ (White et al., 1990) } \\
ITS4 & R: 5'-TCC TCC GCT TAT TGA TAT GC-3' & \\
\hline matK-1KIM & F: 5'-ACC CAG TCC ATC TGG AAA TCT TGG TTC-3' & (Dunning and Savolainen, \\
matK-3KIM & R: 5'-CGT ACA GTA CTT TTG TGT TTA CGA G-3' & 2010) \\
\hline
\end{tabular}

PCR products were purified by using Kits (Promega company-Madison-USA). The purified PCR products were sent to the National Science and Technology Development Agency (NSTDA) in Thailand for sequencing.

\section{Sequence Alignment}

All the DNA sequences were edited and aligned with the ClastalW option available in BioEdit, Version 7.0.4.1 (Hall, 2001), and manual adjustment. There are seven accessions for each $m a t K-F$ and ITS regions, including the out-group species.

\section{Phylogenetic Analyses}

\section{Maximum Parsimony Analysis}

The reconstruction of the phylogenetic relationships was based on Maximum Parsimony (MP) methods. The analysis was carried out for separate and combined regions. MP analysis was performed by using PAUP* version 4.0a164 (Swofford, 2000). Using heuristic search with 100 replicates of random taxon additions, Tree-BisectionReconnection (TBR) branch swapping, MulTrees on, and steepest descent off was performed. The maximum numbers of saved trees were 100 for each replicate. The bootstrap values were calculated from 100 replicates; the consistency index (CI), retention index (RI), rescaled consistency, and homoplasy index (HI) were measured (Felsenstein, 1985).

\section{Bayesian Analysis}

Bayesian analysis was carried out by using the MrBayes version. 3.2 (Ronquist and Huelsenbeck, 2003). The parameters and evolutionary models were selected by the assistant of MrModeltest2 version 2.3 (Nylander et al., 2004), based on Akaike Information Criterion (AIC), which selected the GTR+G model for regions. Two independent analyses were run 1000000 generations with four chains (one cold and three 
heated) for each generation and the temperature parameter set to 0.1 . Trees were sampled every 100 th generations. After that ( $25 \%$ of initial tree sampled) were removed by burnin period samples, a tree with a maximum $50 \%$ (majority rule consensus tree) was plotted. The value of posterior probability (PP) was calculated, and the final tree was plotted by using FigTree software version 1.4.3 (Rambaut, 2016).

\section{Results}

The characteristics of each data matrix and tree statistics of matK and ITS regions are summarized in (Table 2).

Table 2. A summary of alignment and tree statistics of matK, ITS and combined analyses

\begin{tabular}{c|c|c|c}
\hline Parameters/Regions & mat $\boldsymbol{K}$ & ITS & Combined \\
\hline Aligned length & 873 & 362 & 1343 \\
Number of parsimony informative characters & 208 & 70 & 204 \\
Number of variable parsimony uninformative characters & 517 & 231 & 544 \\
Number of constant characters & 148 & 61 & 595 \\
Tree length (steps) & 1134 & 380 & 1097 \\
CI (Consistency Index) & 0.873 & 0.934 & 0.846 \\
RI (Retention Index) & 0.489 & 0.833 & 0.501 \\
RC (Rescaled Index) & 0.427 & 0.779 & 0.424 \\
HI (Homoplasy index) & 0.304 & 0.066 & 0.154 \\
Model & GTR+G & GTR+G & GTR+G \\
\hline
\end{tabular}

In this study, plant genomic DNA was extracted from entire plant tissue by using the Presto $^{\text {TM }}$ Mini gDNA Bacteria Kit. Isolated genomic DNA was electrophoresed on $0.8 \%$ agarose gel to confirm the integrity of the isolated DNA (Fig. 2).

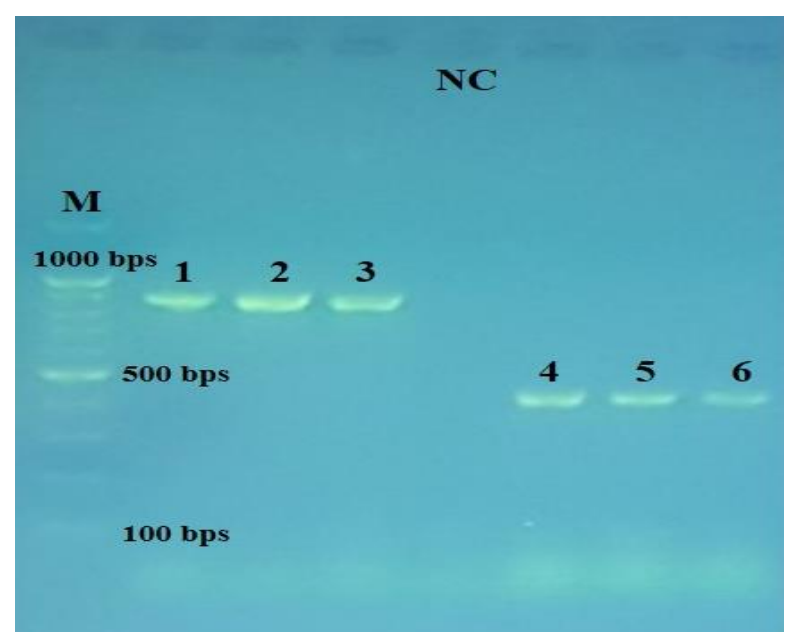

Figure 2. Agarose gel electrophoresis of products using matK-KIM and ITS primers from studied taxa of Michauxia, Asyneuma, and Legousia. M: DNA marker with 100 bps. Lanes 1-3: positive amplification of 900 bps for matK-KIM gene (Lanes 1: M. nuda, Lanes 2: M. laevigata, Lanes 3: L. falcata). Lane NC: negative control. Lanes 4-6 positive amplification of 400 bps for

ITS gene (Lanes 4: L. speculum-veneris, Lanes 5: L. pentagonia, Lanes 6: A. persicum) 


\section{Phylogenetic relationships within Michauxia, Legousia and Asyneuma}

Three major clades were recovered within Michauxia, Asyneuma and Legousia for matK region and two major clades for nuclear ribosomal DNA ITS tree, although the positions of these clades are varied (Figs. 3, 4 and 5). The analyses were carried out for separate and combined regions, consisted of eight in-groups and one out-group taxa.

The clades of matK region as shown in Figure 3 are as follow: Clade A consists of only Michauxia nuda with bootstrap support ( $\mathrm{bs}=100 \%, \mathrm{pp}=0.67$ ); clade B consists of Legousia falcate, Legousia speculum-veneris, Asyneuma pulchellum and Legousia pentagonia and are highly supported ( $\mathrm{bs}=100 \%, \mathrm{pp}=0.96)$, while the clade $\mathrm{C}$ includes of Michauxia laevigata, Asyneuma persicum and Asyneuma rigidum var. rigidum and are highly supported (bs=100\%, $\mathrm{pp}=0.59)$.

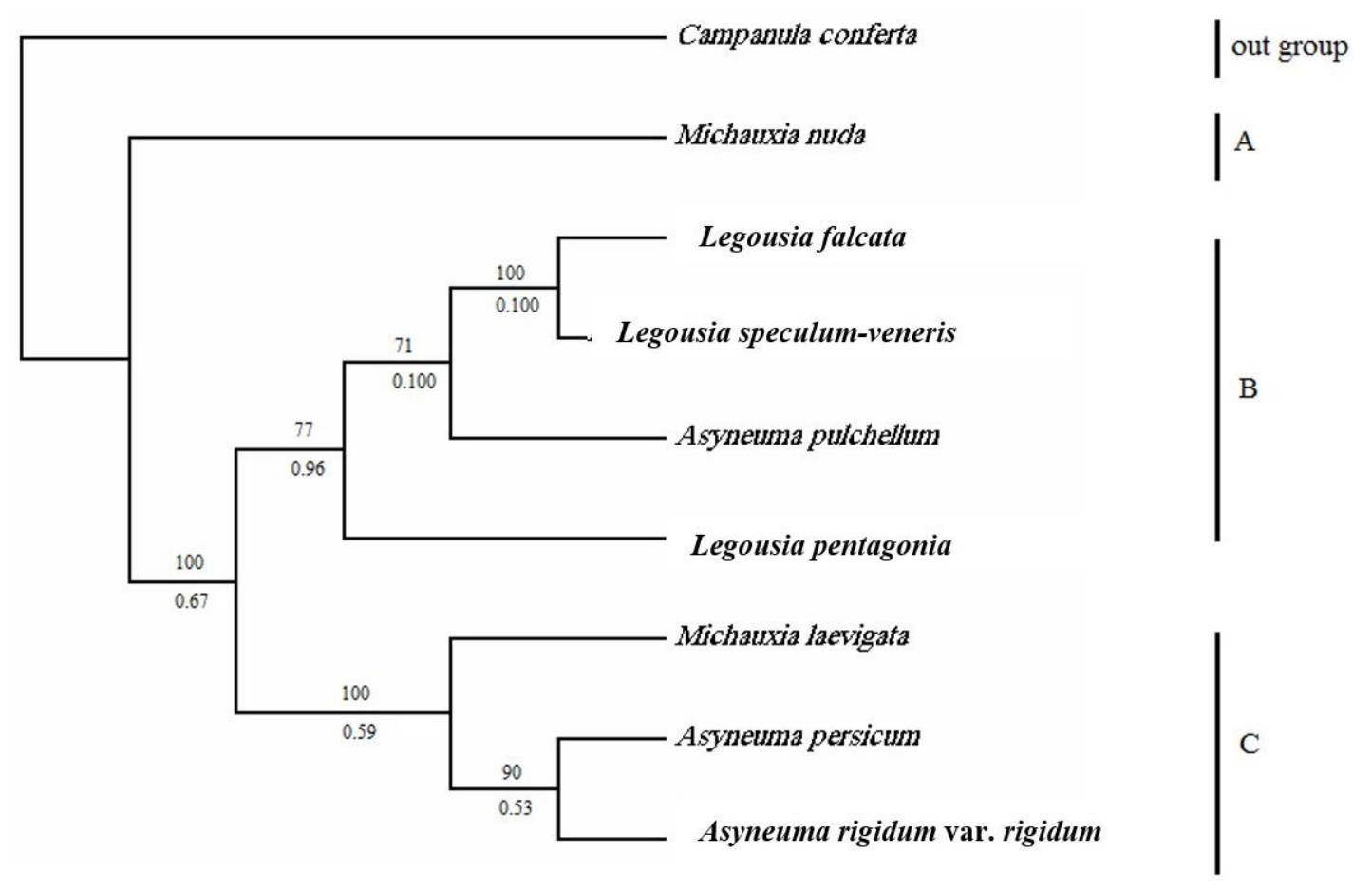

Figure 3. Strict consensus tree of the most parsimonious tree resulting from phylogenetic analysis of the cpDNA matK sequences with a heuristic search using maximum parsimony analysis. (Tree length of 1134 steps, $C I=0.873, R I=0.489, R C=0.427$ and $H I=0.304$ ). Numbers on the branches indicate bootstrap support, and numbers below branches are

Bayesian posterior probability values and clades are identified by letters

The clades of ITS regions as shown in Figure 4 are as follow: Clade A consists of L. falcate, L. speculum-veneris, A. pulchellum and L. pentagonia with bootstrap support ( $\mathrm{bs}=100 \%, \mathrm{pp}=0.98$ ); the clade B consists of M. laevigata, $M$. nuda, A. persicum, and A. rigidum var. rigidum, are highly supported ( $\mathrm{bs}=98 \%, \mathrm{pp}=0.90)$.

The clades of combined regions as shown in Figure 5 are as follow: Clade A consists of $A$. persicum, A. rigidum var. rigidum, $M$. laevigata and $M$. nuda with bootstrap support ( $\mathrm{bs}=76 \%, \mathrm{pp}=0.52$ ); the clade B consists of L. pentagonia, A. pulchellum, A. pulchellum, and L. speculum-veneris and are highly supported ( $\mathrm{bs}=100 \%, \mathrm{pp}=1.00)$. 


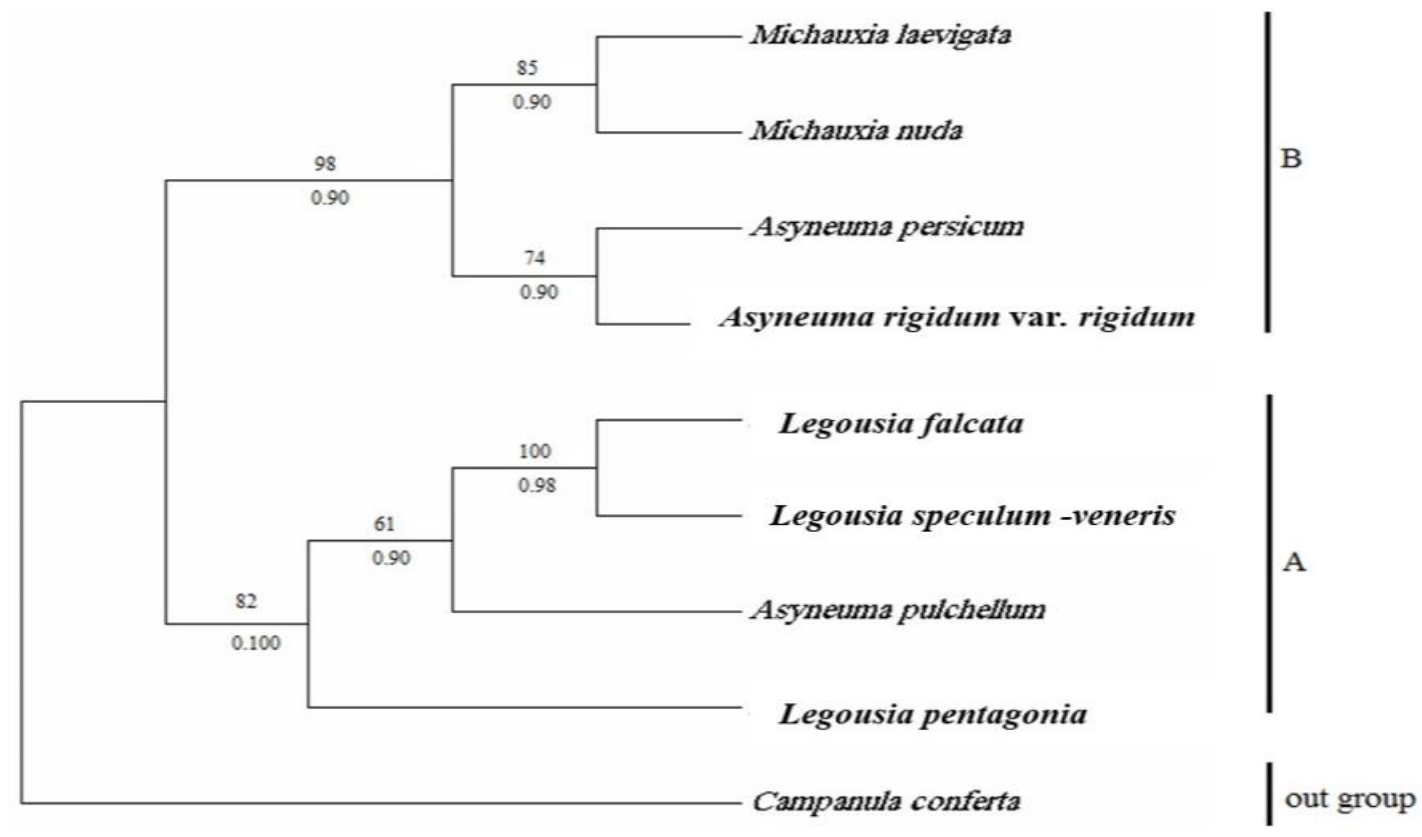

Figure 4. Strict consensus tree of the most parsimonious tree resulting from phylogenetic analysis of the nrDNA ITS sequences with a heuristic search using maximum parsimony analysis. (Tree length of 380 steps, $C I=0.934, R I=0.833, R C=0.779$ and $H I=0.066$ ). Numbers on the branches indicate bootstrap support and numbers below branches are Bayesian posterior probability values and clades are identified by letters

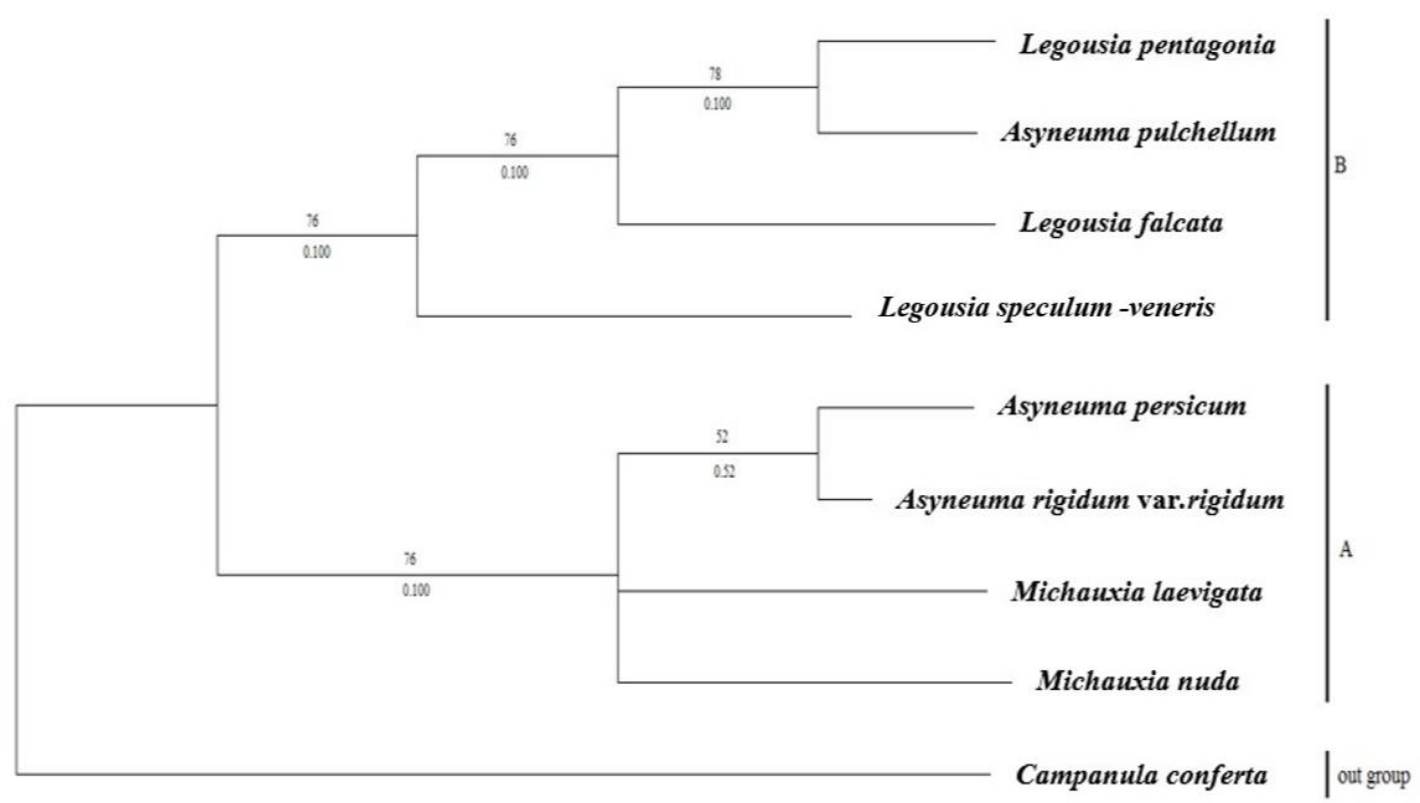

Figure 5. Strict consensus tree of the most parsimonious tree resulting from phylogenetic analysis of the combined sequences with a heuristic search using maximum parsimony analysis. (Tree length of 1097 steps, $C I=0.846, R I=0.501, R C=0.424$ and $H I=0.154$ ). Numbers on the branches indicate bootstrap support and numbers below branches are Bayesian posterior probability values and clades are identified by letters 


\section{Discussion}

\section{Phylogenetic Analysis}

As one of the essential markers in molecular systematics and evolution, mat K and ITS2 show significant sequence variability at the species level or lower. The availability of its structural information permits analysis at a higher taxonomic level, which provides additional information for improving accuracy and robustness in the reconstruction of phylogenetic trees (Coleman, 2003, 2009).

Furthermore, ITS2 is potentially useful as a standard DNA barcode to identify plants and it is regarded as one of the candidate DNA barcodes because of its valuable characteristics, including the availability of conserved regions for designing universal primers, the ease of its amplification, and enough variability to distinguish even closely related species (Chen et al., 2010).

The ITS2 sequence lengths of plants were mainly distributed in the 195-510 bps range. The identification of plant using DNA barcoding techniques is one of the main tasks in natural museums and research institutes. The length of the ITS2 region is sufficiently short to allow amplification of even degraded DNA (Meyer and Paulay, 2005).

Recently,the ITS2 region has been found to vary in primary sequences and secondary structures in a way that correlates highly with taxonomic classification. Several researchers have already demonstrated the potential for using ITS2 for taxonomic classification and phylogenetic reconstruction at both the genus and species levels for eukaryotes, including animals, plants, and fungi (Schultz et al., 2005; Coleman, 2007; Schultz and Wolf, 2009).

Based on the analysis of nuclear chloroplast matK data, the species $M$. nuda shared a single sister branch for all other taxa with supports ( $\mathrm{bs}=100 \%, \mathrm{pp}=0.6)$, due to the unusual occurrence and habit. It has differed with both clades B and $C$ in some features as the species has between 7-9 number of calyx, corolla and stamens, present of small appendages of calyx, the shape of the inflorescence is narrowly conical and also the color of the flower is yellow (Fedorov, 1999). Phylogenetic relationships of clade B include four species. L. falcata phylogenetically nearest to L. speculum-veneris, they are monophyletic in this clade (bootstrap support $(\mathrm{bs}=100 \%, \mathrm{pp}=0.100)$ ) and differs morphologically from each other by calyx lobes, in L. falcata, the calyx lobes reflexed or curved downwards while in L. speculum-veneris the calyx lobes are erect and ascending (Ghazanfar and Edmondson, 2013). The species A.pulchellum has related with the monophyletic group in this clade $(\mathrm{bs}=71 \%, \mathrm{pp}=0.100)$, the main difference among related monophyletic group is biennial herbs with A. pulchellum and annual herbs in the monophyletic group, in the other hand, L. pentagonia was related to above-closed group ( $\mathrm{bs}=77 \%, \mathrm{pp}=0.96$ ). The L. pentagonia distinguishes with the related monophyletic group by the calyx lobes, which is half as long as the ovary and its capsule not constricted at the apex (Damboldt and Davis, 1978).

The clade $\mathrm{C}$ comprises three species, which include $M$. laevigata, with(and) the monophyletic group $A$. persicum and $A$. rigidum var. rigidum. The phylogenic relationship within this clade is that $A$. persicum and $A$. rigidum var. rigidum was classified in a monophyletic group with bootstrap support $(\mathrm{bs}=90 \%, \mathrm{pp}=0.53$ ) due to that both species are perennial herbs with black violet flowers and five stamens which are free while they differ in the shape of capsule and leaves. The capsule in A. persicum with nodding shape and dehiscent by 3 valves to the middle of the apex and the leaves shape are between linear to lanceolate while in the closed species, the capsule is oblong and 
dehiscent by 3 valves to the end of the apex with the presence of oblong leaves (Rechinger, 1965). The species M. laevigata related monophyletic to the two first species in this clade with ( $\mathrm{bs}=100 \%, \mathrm{pp}=0.59)$. The main difference was observed within this clade is the number of stamens and colors of flowers. The stamens number of $M$. laevigata is between 8-10, and the intensity of flower color is yellow, while in both species in the monophyletic group, the number of the stamens is 5 and the color of the flower is violet (Tutin et al., 1993).

Phylogenetic analysis of the nrDNA ITS sequences showed two clades A and B with out-group Campanula conferta. The clade A includes four species. L. falcata phylogenetically nearest to L. speculum-veneris (bootstrap support ( $\mathrm{bs}=100 \%$, $\mathrm{pp}=0.98)$ ) and differs morphologically from each other by the shape of corolla lobes, in L. falcata, the corolla lobes are acute. In contrast, in L. speculum-veneris, the corolla lobes are mucronate (Wahlsteen and Tyler, 2019).

The species A.pulchellum has related to the monophyletic group in this clade (bs=61\%, $\mathrm{pp}=0.90$ ), this species differs by having free corolla lobs, while the species in the monophyletic group have united corolla lobs (Ghazanfar and Edmondson, 2013). On the other hand, the species L. pentagonia was related to the above closed group (bs $=82 \%$, $\mathrm{pp}=0.100$ ), this species discriminates from other species in this clade by having longer calyx lobes than the corolla tube and has ciliated filaments at the base. The clade B consist of four species in two monophyletic groups, the first group consists of $M$. nuda and M. laevigata ( $\mathrm{bs}=85 \%, \mathrm{pp}=0.90$ ) due to the two species are biennial herbs and share in many features, while the second monophyletic group includes the two species A. persicum and $A$. rigidum var. rigidum ( $\mathrm{bs}=74 \%, \mathrm{pp}=0.90$ ) because both are perennial herbs and have dilated filament at base (Rechinger, 1965).

\section{Conclusions}

In the present study three major clades within the species of the genera Michauxia, Asyneuma and Legousia were identified in the matK-KIM tree compared to combined tree which consists of only two clades, in the matK-KIM tree the clade A consists only of M. nuda; clade B consists of L. falcate, L. speculum-veneris, A. pulchellum and $L$. pentagonia while the clade $\mathrm{C}$ consists of $M$. laevigata, $A$. persicum and A. rigidum var. rigidum while in the combined tree the species $M$. nuda found in the clade A within the species $M$. laevigata, $A$. persicum and $A$. rigidum var. rigidum, the clade $\mathrm{B}$ in both trees are similar. The clades of ITS regions consist of two clades are as follow: Clade A consists of L. falcate, L. speculum-veneris, A. pulchellum and L. pentagonia, the clade A in ITS tree is similar to the clade B of the combined tree while the clade B in ITS tree is similar to the clade $\mathrm{A}$ in the combined tree. We suggest phylogenic analysis for all genera in the campanulacese family in Iraq and that helps to know the more molecular relationship among the family genera.

\section{REFERENCES}

[1] Boissier, E. (1875): Campanulaceae. - Flora orientalis 3: 884-962.

[2] Byng, J. W. (2014): The flowering plants handbook: A practical guide to families and genera of the world. - Plant Gateway Ltd.

[3] Carolin, R. C. (1977): The systematic relationships of Brunonia. - Brunonia 1: 9-29. 
[4] CBOL Plant Working Group (Hollingsworth, P. M., Forrest, L. L., Spouge, J. L., Hajibabaei, M., Ratnasingham, S., Van Der Bank, M., Chase, M. W., Cowan, R. S., Erickson, D. L.) (2009): A DNA barcode for land plants. - Proceedings of the National Academy of Sciences 106: 12794-12797.

[5] Charadze, A. (1949): A treatment of the systematics of the Caucasian species of the genus Campanula section Medium A. DC. - Zametki Sist. Geogr. Rast 15: 13-33.

[6] Charadze, A. (1970): On the florogenesis of the Caucasian Campanulas. - Zametki Sist. Geogr. Rast 28: 89-102.

[7] Charadze, A. (1976): The genus Campanula L. sl in the Caucasus (Conspectus). - Zametki Sist. Geogr. Rast 32: 45-56.

[8] Chen, S., Yao, H., Han, J., Liu, C., Song, J., Shi, L., Zhu, Y., Ma, X., Gao, T., Pang, X. (2010): Validation of the ITS2 region as a novel DNA barcode for identifying medicinal plant species. - PloS One 5.

[9] Coleman, A. W. (2003): ITS2 is a double-edged tool for eukaryote evolutionary comparisons. - TRENDS in Genetics 19: 370-375.

[10] Coleman, A. W. (2007): Pan-eukaryote ITS2 homologies revealed by RNA secondary structure. - Nucleic Acids Research 35: 3322-3329.

[11] Coleman, A. W. (2009): Is there a molecular key to the level of "biological species" in eukaryotes? A DNA guide. - Molecular phylogenetics and evolution 50: 197-203.

[12] Cosner, M., Jansen, R., Crawford, D. (1991): Structural Variation and Evolution of Chloroplast DNA in the Campanulaceae. - American Journal of Botany 78: 92.

[13] Cosner, M., Jansen, R. (1993): Evolution of chloroplast DNA structure in the Campanulaceae. - American Journal of Botany 80: 140.

[14] Cosner, M. E., Jansen, R. K., Lammers, T. G. (1994): Phylogenetic relationships in theCampanulales based onrbcL sequences. - Plant systematics and evolution 190: 79-95.

[15] Cosner, M. E., Raubeson, L. A., Jansen, R. K. (2004): Chloroplast DNA rearrangements in Campanulaceae: phylogenetic utility of highly rearranged genomes. - BMC evolutionary biology 4: 27.

[16] Cronquist, A. (1981): An integrated system of classification of flowering plants. Columbia University Press.

[17] Cronquist, A. (1988): The evolution and classification of flowering plants. - Thomas Nelson \& Sons Ltd., London.

[18] Crowl, A. A., Mavrodiev, E., Mansion, G., Haberle, R., Pistarino, A., Kamari, G., Phitos, D., Borsch, T., Cellinese, N. (2014): Phylogeny of Campanuloideae (Campanulaceae) with emphasis on the utility of nuclear pentatricopeptide repeat (PPR) genes. - PLOS One 9(4): e94199.

[19] Crowl, A. A., Miles, N. W., Visger, C. J., Hansen, K., Ayers, T., Haberle, R., Cellinese, N. (2016): A global perspective on Campanulaceae: Biogeographic, genomic, and floral evolution. - American journal of botany 103: 233-245.

[20] Damboldt, J., Davis, P. (1978): Flora of Turkey. - Edinburgh.

[21] De Candolle, A. (1839): Campanulaceae. Prodromus systematis naturalis regni vegetabilis. - Paris: Treuttel et Würtz.

[22] Drummond, A. J., Ho, S. Y., Phillips, M. J., Rambaut, A. (2006): Relaxed phylogenetics and dating with confidence. - PLoS Biology 4.

[23] Dunning, L. T., Savolainen, V. (2010): Broad-scale amplification of matK for DNA barcoding plants, a technical note. - Botanical Journal of the Linnean Society 164: 1-9.

[24] Eddie, W., Shulkina, T., Gaskin, J., Haberle, R., Jansen, R. K. (2003): Phylogeny of Campanulaceae s. str. inferred from ITS sequences of nuclear ribosomal DNA. - Annals of the Missouri Botanical Garden 9: 554-575.

[25] Evans, T. M., Jabaily, R. S., De Faria, A. P. G., De Sousa, L. D. O. F., Wendt, T., Brown, G. K. (2015): Phylogenetic relationships in Bromeliaceae subfamily Bromelioideae based on chloroplast DNA sequence data. - Systematic Botany 40: 116-128. 
[26] Faghir, M. B., Attar, F., Farazmand, A., Osaloo, S. K. (2014): Phylogeny of the genus Potentilla (Rosaceae) in Iran based on nrDNA ITS and cpDNA trnL-F sequences with a focus on leaf and style characters' evolution. - Turkish Journal of Botany 38: 417-429.

[27] Fedorov, A. (1957): Campanulaceae. - In: Shishkin, B. K. (ed.) Flora of the USSR, Vol. 24. Akademia Nauk. Moskva Press, Russia.

[28] Fedorov, А. А. (1999): Flora of Russia, Рипол Классик.

[29] Felsenstein, J. (1985): Confidence limits on phylogenies: an approach using the bootstrap. - Evolution 39: 783-791.

[30] Ghazanfar, S., Edmondson, J. (2013): Flora of Iraq. - Royal Botanic Gardens, Kew, London, pp.180-185.

[31] Haberle, R. C. (2006): Phylogeny and comparative chloroplast genomics of the Campanulaceae. - Dissertation, The University of Texas at Austin.

[32] Hall, R. E. (2001): The stock market and capital accumulation. - American Economic Review 91: 1185-1202.

[33] Hansen, K. M. (2016): Phylogeny, Biogeography, Floral Morphology Of Cyphocarpoideae (Campanulaceae). - Northern Arizona University.

[34] Hutchinson, J. (1969): Evolution and phylogeny of flowering plants: dicotyledons, facts and theory. - Academic Press, 717p.

[35] Meyer, C. P., Paulay, G. (2005): DNA barcoding: error rates based on comprehensive sampling. - PLoS Biology 3.

[36] Nylander, J. A., Ronquist, F., Huelsenbeck, J. P., Nieves-Aldrey, J. (2004): Bayesian phylogenetic analysis of combined data. - Systematic biology 53: 47-67.

[37] Rambaut, A. (2016): FigTree version 1.4. 0. - Available at http://tree. bio. ed. ac. uk/software/figtree. Accessed November.

[38] Rechinger, K. (1965): Flora Iranica (150 parts published out of a projected 170). - GranzAustria: Akademische Drucku: Verlagsanstalt, 1977.

[39] Ree, R. H., Moore, B. R., Webb, C. O., Donoghue, M. J. (2005): A likelihood framework for inferring the evolution of geographic range on phylogenetic trees. - Evolution 59: 22992311.

[40] Ronquist, F., Huelsenbeck, J. P. (2003): MrBayes 3: Bayesian phylogenetic inference under mixed models. - Bioinformatics 19: 1572-1574.

[41] Sanderson, M. J. (2002): Estimating absolute rates of molecular evolution and divergence times: a penalized likelihood approach. - Molecular biology and evolution 19: 101-109.

[42] Schönland, S. (1889): Campanulaceae. - Die Naturichen Planzenfamilien. A. E. K. Prantl. Leipzig, W. Engelman IV. 5: 40-70.

[43] Schultz, J., Maisel, S., Gerlach, D., Müller, T., Wolf, M. (2005): A common core of secondary structure of the internal transcribed spacer 2 (ITS2) throughout the Eukaryota. Rna 11: 361-364.

[44] Schultz, J., Wolf, M. (2009): ITS2 sequence-structure analysis in phylogenetics: a how-to manual for molecular systematics. - Molecular phylogenetics and evolution 52: 520-523.

[45] Swofford, D. (2000): PAUP (Phylogenetic Analysis Using Parsimony). Documentation for Version 4.0 b4a Sinauer Associates. - Inc. Publishers, Sunderland, Massachusetts.

[46] Takhtajan, A. (2009): Flowering plants. - Springer Science \& Business Media.

[47] Thorne, J. L., Kishino, H. (2002): Divergence time and evolutionary rate estimation with multilocus data. - Systematic biology 51: 689-702.

[48] Tutin, T. G., Burges, N. A., Chaterj, A. O., Edmondson, R., Heywood, V. H., Moore, D. M., Valentine, D. H. (1993): Flora Europaea. - Cambridgeshire, UK, Cambridge University Press.

[49] Wahlsteen, E., Tyler, T. (2019): Morphometric analyses and species delimitation in Legousia (Campanulaceae). - Willdenowia 49: 21-33.

[50] Watson, L., Dallwitz, M. (1992): The families of flowering plants: descriptions, illustrations, identification and information retrieval. - University of New Orleans. 


$$
\text { - } 5460 \text { - }
$$

[51] White, T. J., Bruns, T., Lee, S., Taylor, J. (1990): Amplification and direct sequencing of fungal ribosomal RNA genes for phylogenetics. - PCR protocols: a guide to methods and applications 18: 315-322.

[52] Yao, H., Song, J., Liu, C., Luo, K., Han, J., Li, Y., Pang, X., Xu, H., Zhu, Y., Xiao, P. (2010): Use of ITS2 region as the universal DNA barcode for plants and animals. - PloS One 5: 1-9.

[53] Yu, F., Bi, C., Wang, X., Qian, X., Ye, N. (2018): The complete mitochondrial genome of Citrus sinensis. - Mitochondrial DNA Part B 3: 592-593. 